\title{
Ovulation rate and embryo survival in Damline ewes after treatment with bovine follicular fluid in the luteal phase of the oestrous cycle*
}

\author{
Jacqueline M. Wallace, A. S. McNeilly and D. T. Baird \\ MRC Reproductive Biology Unit, Department of Obstetrics and Gynaecology, University of Edinburgh, \\ Centre for Reproductive Biology, 37 Chalmers Street, Edinburgh EH3 9EW, U.K.
}

\begin{abstract}
Summary. Treatment of Damline ewes with twice daily i.v. injections of bovine follicular fluid during the luteal phase for 10,6 or 2 days before prostaglandin-induced luteolysis resulted in an increase in ovulation rate. This was associated with a large rebound increase in plasma concentrations of FSH after the last injection of bovine follicular fluid. While conception rate was not affected by bovine follicular fluid treatment, a higher percentage embryonic loss was observed between Days 3 and 34 of pregnancy in the 10-day treatment group only compared to controls. This reflected the increase in ovulation rate above the optimum for embryonic survival in this breed. The present results suggest that the increase in ovulation rate induced by bovine follicular fluid treatment in the luteal phase of the cycle before mating would result in a significant increase in the number of lambs born.
\end{abstract}

\section{Introduction}

The number of eggs shed by the ovaries sets the upper limit to production and there is no doubt that a low ovulation rate is one of the major factors currently limiting lambing percentages of ewe flocks throughout the world. Wallace \& McNeilly (1985) have shown that twice daily injections of charcoal-treated bovine follicular fluid throughout the luteal phase of the cycle result in a moderate, but significant, increase in ovulation rate at the following oestrus. The production of partly or completely pure preparations of inhibin, thought to be the major active component of follicular fluid, is imminent (de Jong, van Dijk \& van der Molen, 1984), and therefore the possible practical significance of such a treatment is important. As with all other available non-genetic methods of increasing ovulation rate, such as immunization against steroids (Van Look, Clarke, Davidson \& Scaramuzzi, 1978), administration of PMSG (Robinson, 1951; Gherardi \& Lindsay, 1980), and short-term (Davis, Brien, Findlay \& Cumming, 1981) and long-term (Gunn, Doney \& Russel, 1969) nutritional treatments, it is vital to determine whether an increase in ovulation rate is reflected by increased lambing percentages.

The present study had two main objectives; firstly to determine the length of treatment with bovine follicular fluid required to produce an increase in ovulation rate, and secondly to determine whether the increase in ovulation rate was reflected by a greater number of embryos surviving at Day 30 of gestation.

\section{Materials and Methods}

Experimental animals. Forty Damline ewes (47\% Finnish Landrace, 24\% East Friesland, 17\% Border Leicester, 12\% Dorset Horn) were studied during the breeding season in OctoberDecember 1983 . The ewes were between $1 \frac{1}{2}$ and $2 \frac{1}{2}$ years of age and initially weighed $42.6 \pm 3.8 \mathrm{~kg}$

\footnotetext{
* Reprint requests to Dr A. S. McNeilly.
} 
The animals were at pasture throughout the period of synchronization of oestrus and pregnancy and housed indoors during the treatment cycle at Dryden Field Station, Roslin, Midlothian, U.K.

The initial synchrony was achieved by withdrawing progestagen-impregnated intravaginal pessaries (Intervet Laboratories Ltd, Cambridge, U.K.) 12 days after their insertion. All ewes displayed behavioural oestrus within $48 \mathrm{~h}$ as determined by a raddled vasectomized ram. Luteolysis was then induced on Day 10 of the second cycle via an i.m. injection of a potent analogue of prostaglandin F-2 $\alpha$ (100 $\mu$ g cloprostenol; ICI, Cheshire, U.K.). Oestrus was detected as before and the ewes moved inside before the start of the treatment cycle on Day 1 (oestrus plus $24 \mathrm{~h}$ ).

Experimental design. Ewes were weighed, ranked and allocated to one of 4 treatments so that weights were equivalent between treatments before the start of the study.

Bovine follicular fluid was collected and extracted with charcoal to remove steroids as described previously (McNeilly, 1984; Wallace \& McNeilly, 1985). Bovine serum was treated in an identical manner and used as a control fluid. The inhibin activity of the follicular fluid was measured in this laboratory using an in-vitro pituitary cell culture system exactly as described previously (Tsonis et al., 1983) and was found to have a potency of $11957 \mathrm{U} / \mathrm{ml}$.

Ewes in Group FF10 $(\mathrm{N}=10)$ received $9 \mathrm{ml}$ bovine follicular fluid i.v. at 09:00 and 17:00 h on Days 1-10 inclusive of the treatment cycle. Ewes in Group FF6 $(\mathrm{N}=10)$ received $9 \mathrm{ml}$ charcoalextracted bovine serum twice daily for the first 4 days of the cycle followed by $9 \mathrm{ml}$ bovine follicular fluid twice daily for the next 6 days of the cycle. Ewes in Group FF2 $(N=10)$ received charcoalextracted bovine serum for 8 days followed by bovine follicular fluid twice daily for 2 days. Ewes in Group $C(N=10)$ received charcoal-extracted bovine serum at 09:00 and 17:00 $\mathrm{h}$ for the entire 10 days.

Luteal regression was induced in all ewes at 10:00 h on Day 11 of the treatment cycle using prostaglandin as described previously. The onset of behavioural oestrus was assessed using a ram at 12-h intervals (08:00 and 20:00 h) between 22 and $142 \mathrm{~h}$ after cloprostenol injection. All ewes were hand-mated with a fertile ram at the first recorded onset of oestrous behaviour and again $12 \mathrm{~h} \mathrm{later,}$ different rams being used on both occasions. Ovulation rate was assessed by laparoscopy between Days 5 and 10 of the cycle. Two raddled vasectomized rams were run with the ewes for 24 days after mating and those ewes that did not again demonstrate oestrous behaviour were considered to be pregnant.

Blood sampling. Blood samples $(10 \mathrm{ml})$ were taken twice daily throughout the treatment before follicular fluid or serum injection and daily after cloprostenol-induced luteolysis until oestrus was detected. Thereafter samples were withdrawn on every 2 nd or 3rd day until Day 20 or 21 . All samples were assayed for LH, FSH and progesterone.

Slaughter procedures. All pregnant ewes were slaughtered between Days 31 and 34 of gestation and the intact gravid uterus and ovaries were removed immediately and placed on ice. The ovaries were dissected to determine the number and weight of corpora lutea present. The gravid uterus was opened by a dorsal mid-line incision, taking care not to rupture the placental tissue. The fetal cotyledons were separated from the cotyledonary burrs on the uterine epithelium by gentle traction. The position, number and macroscopic appearance of the fetuses were recorded for each dissected uterus. After ligation of the umbilical cords, the fetuses were detached from their placentae, measured and weighed. Due to the small size of the fetuses at this early stage of gestation it was only feasible to measure the straight crown-rump and head lengths.

Hormone assays. LH and FSH in plasma were measured in duplicate by specific doubleantibody radioimmunoassays as described previously (Martensz, Baird, Scaramuzzi \& Van Look, 1976; McNeilly, McNeilly, Walton \& Cunningham, 1976). The sensitivities of the assays were $0.2 \mathrm{ng} \mathrm{LH}$ (NIH-LH-S18)/ml and $4 \mathrm{ng} \mathrm{FSH} \mathrm{(NIH-FSH-S14)/ml} \mathrm{and} \mathrm{the} \mathrm{intra-} \mathrm{and} \mathrm{inter-assay} \mathrm{vari-}$ ations as coefficients of variation were respectively $4 \cdot 5 \%$ and $5 \cdot 8 \%$ for $\mathrm{LH}$ and $4.0 \%$ and $8 \cdot 3 \%$ for 
FSH. Progesterone concentrations in plasma were measured by radioimmunoassay as described previously (Djahanbahkch, Swanston, Corrie \& McNeilly, 1981) with intra- and inter-assay coefficients of variation of $15 \%$ and $10 \%$ and a sensitivity of $0.1 \mathrm{ng} / \mathrm{ml}$. Recovery of progesterone added to $250 \mu$ l sheep plasma was $61 \pm 3 \%$ (s.e.m.; $n=100$ ).

Statistics. The effect of treatment on onset of oestrus, ovulation rate and embryo survival was determined using analysis of variance followed by Duncan's New Multiple Range Test where appropriate. The differences in hormone concentrations between the groups were also analysed by analysis of variance.

\section{Results}

\section{Reproductive performance}

Onset of oestrus. Oestrous behaviour was observed in 38 of the 40 ewes originally allocated to the experiment. Although the onset of oestrus was slightly earlier in Group C ewes relative to those in Groups FF2, FF6 and FF10, the differences were not significant (Table 1).

Table 1. Effect of treatment with bovine follicular fluid on onset of oestrus, ovulation, conception and pregnancy rates in ewes

\begin{tabular}{|c|c|c|c|c|c|c|}
\hline & \multirow[b]{2}{*}{$\begin{array}{l}\text { Total no. of } \\
\text { ewes showing } \\
\text { oestrus }\end{array}$} & \multirow[b]{2}{*}{$\begin{array}{c}\text { Mean } \pm \text { s.e.m. } \\
\text { onset } \\
\text { of oestrus (h) }\end{array}$} & \multicolumn{2}{|c|}{$\underset{\text { (range) }}{\text { Mean } \pm \text { s.e.m. ovulation rate }}$} & \multicolumn{2}{|c|}{ No. of ewes } \\
\hline & & & $\begin{array}{c}\text { At } \\
\text { laparoscopy }\end{array}$ & $\begin{array}{c}\text { At } \\
\text { slaughter }\end{array}$ & $\begin{array}{l}\text { Conceiving } \\
\text { (non-return } \\
\text { rate) }\end{array}$ & $\begin{array}{l}\text { Pregnant } \\
\text { at slaughter }\end{array}$ \\
\hline Group C & -9 & $62 \cdot 8 \pm 9 \cdot 9-$ & $\begin{array}{c}2 \cdot 6 \pm 0 \cdot 2^{\mathrm{a}} \\
(\mathrm{N}=9)^{-}\end{array}$ & $\begin{array}{c}3 \cdot 1 \pm 0 \cdot 2^{\mathrm{e}} \\
(\mathrm{N}=8) \\
(2-4)\end{array}$ & -8 & -8 \\
\hline Group FF2 & 10 & $86 \cdot 7 \pm 10 \cdot 8$ & $\begin{array}{c}3 \cdot 4 \pm 0 \cdot 2^{b} \\
(\mathrm{~N}=10)\end{array}$ & $\begin{array}{c}3 \cdot 5 \pm 0 \cdot 2^{\mathrm{f}} \\
(\mathrm{N}=8) \\
(3-4)\end{array}$ & 10 & 8 \\
\hline Group FF6 & 10 & $78 \cdot 4 \pm 8 \cdot 7$ & $\begin{array}{l}3 \cdot 4 \pm 0 \cdot 3^{c} \\
(N=10)\end{array}$ & $\begin{array}{c}3 \cdot 6 \pm 0 \cdot 5^{\mathrm{B}} \\
(\mathrm{N}=9) \\
(3-7)\end{array}$ & -9 & 9 \\
\hline Group FFI0 & -9 & $66 \cdot 7 \pm 7 \cdot 1-$ & $\begin{array}{c}4 \cdot 7 \pm 0 \cdot 2^{d} \\
(N=9)\end{array}$ & $\begin{array}{c}5 \cdot 0 \pm 0 \cdot 3^{\mathrm{b}} \\
(\mathrm{N}=9) \\
(4-7)\end{array}$ & -9 & 9 \\
\hline
\end{tabular}

$a b, a c, c d, g h, P<0.05 ; b d, f h, P<0.01 ; a d, e h, P<0.001$.

Conception rate. Whether or not the ewes had conceived was initially determined from the non-return rate, i.e. those ewes that did not return to oestrus as determined from markings by a raddled vasectomized ram during the 12-24 days after mating. Two ewes (one in Group $\mathrm{C}$ and one in Group FF6) returned to oestrus within this period. At slaughter a further 2 ewes both from Group FF2 were not pregnant but were still cycling. It seemed unlikely from examination of the uteri that either of them had originally conceived. Conception rate between groups was not significantly different, giving an overall conception rate of $89 \%$ for ewes mated.

Ovulation rate. The design of the experiment allowed a comparison to be made between the number of corpora lutea observed at laparoscopy with that found on dissection of the ovaries at slaughter (Table 1). A total of 8 'additional' corpora lutea were found at slaughter. They were all without exception very small relative to the other corpora lutea on the ovary and tended to be 
buried between them. These 'additional' corpora lutea were randomly spread throughout the four groups but did alter the mean ovulation rate and significance levels as shown in Table 1. At laparoscopy the ewes in Groups FF2, FF6 and FF10 had a significantly higher mean ovulation rate than did those in Group $\mathrm{C}(P<0.05, P<0.05, P<0.001$ respectively). However, of the ewes pregnant at slaughter, only the mean ovulation rate of ewes in Group FF10 was significantly different from that of controls $(P<0.001)$. In addition, the ewes in Group FF10 had a significantly higher mean ovulation rate than did those in Group FF6 and Group FF2 $(P<0.05$ and $P<0.01$ respectively). This highlights a degree of error $(6 \%)$ in using the laparoscope as the sole experimental tool when measuring ovulation rate, particularly when multiple corpora lutea may be involved. The majority of ewes ovulated from both ovaries but 6 ewes $(16 \%)$ failed to ovulate from the right, and 6 from the left ovary; these ewes occurred randomly in the groups.

Embryo survival. The number of viable fetuses at slaughter varied from 1 to 4 with an overall mean ( \pm s.e.m.) of $2 \cdot 4 \pm 0 \cdot 2$. The significant increase in the number of ova shed after follicular fluid treatment was not proportionally reflected by the number of embryos surviving at Day 31-34 of pregnancy as is shown in Table 2. However the projected lambing percentages show that an overall increase of 21 and 77 lambs born per 100 ewes in Groups FF6 and FF10, respectively could be expected on the basis of this study. Although the ewes in Group FF10 had a higher number of embryos surviving when compared with controls, the percentage of embryonic survival in this group was $10 \%$ less than that of controls. The values for ewes in Groups FF6 and FF2 were intermediate between the two.

Only $32 \%$ of the ewes had all their corpora lutea represented by viable fetuses at slaughter. This was not influenced by treatment in that ewes with maximum $(100 \%)$ embryonic survival were found in all 4 groups. However, it was affected by ovulation rate as $91 \%$ of these ewes had an

Table 2. Effect of treatment with bovine follicular fluid on the number of viable fetuses, embryo survival and projected lambing percentages in Damline ewes

\begin{tabular}{lcccccc}
\hline & $\begin{array}{c}\text { No. } \\
\text { of } \\
\text { ewes }\end{array}$ & $\begin{array}{c}\text { Total no. } \\
\text { of CL } \\
\text { at slaughter }\end{array}$ & $\begin{array}{c}\text { Total no. } \\
\text { of } \\
\text { fetuses }\end{array}$ & $\begin{array}{c}\text { Mean } \pm \text { s.e.m. no. } \\
\text { of fetuses } \\
\text { (range) }\end{array}$ & $\begin{array}{c}\text { Projected } \\
\text { lambing } \\
\%\end{array}$ & $\begin{array}{c}\% \\
\text { embryonic } \\
\text { survival }\end{array}$ \\
\hline Group C & 8 & 25 & 17 & $\begin{array}{c}2 \cdot 12 \pm 0 \cdot 22 \\
(1-3)\end{array}$ & 212 & $68^{\mathrm{a}}$ \\
Group FF2 & 8 & 28 & 17 & $\begin{array}{c}2 \cdot 12 \pm 0 \cdot 35 \\
(1-3)\end{array}$ & 212 & $61^{\mathrm{b}}$ \\
Group FF6 & 9 & 32 & 21 & $\begin{array}{c}2 \cdot 33 \pm 0 \cdot 33 \\
(1-4)\end{array}$ & 233 & $66^{\mathrm{c}}$ \\
Group FF10 & 9 & 45 & 26 & $\begin{array}{c}2 \cdot 89 \pm 0 \cdot 39 \\
(1-4)\end{array}$ & 289 & $58^{\text {d }}$ \\
\hline
\end{tabular}

$a b, a c, a d$, N.S.

Table 3. The relationship between ovulation rate and the proportion of viable fetuses at slaughter, irrespective of treatment group

\begin{tabular}{lcccccc}
\hline Ovulation rate & 2 & -3 & -4 & 5 & 6 & 7 \\
$\begin{array}{l}\text { No. of ewes } \\
\begin{array}{l}\text { Viable fetuses } \\
\text { at slaughter }(\%)\end{array}\end{array}$ & 2 & 14 & 11 & 4 & 1 & 2 \\
\hline
\end{tabular}


ovulation rate of 3 or 4 . Irrespective of treatment, no ewe with an ovulation rate of $>4$ had a full complement of embryos at slaughter. The optimum ovulation rate in the present study was 3 , above which embryonic survival decreased markedly (see Table 3 ).

Ovum wastage and embryo loss. Overall ovum wastage was $36.7 \%$ of the total number of corpora lutea and, as suggested above was related to ovulation rate, being highest in ewes ovulating 4 or more eggs. In many ewes the fate of the lost eggs is unknown, but in 3 ewes ( 1 in Group $C, 1$ in Group FF6 and 1 in Group FF10) eggs had been successfully fertilized and death of the embryo had occurred before implantation. The incidence of detectable embryonic death was too rare, however, to test for any correlation with ovulation rate or length of follicular fluid treatment.

Fetal weight and size. There was no significant effect of treatment on fetal weight or size (data not shown).

\section{Hormonal data}

Plasma concentrations of FSH and $L H$. The changes in plasma FSH values throughout the treatment cycle are illustrated in Text-fig. 1. The first two samples taken on Day 1 from ewes in Groups C, FF2 and FF6 reflect the high plasma FSH concentrations normally seen during the period of the second FSH surge. The first follicular fluid injection (09:00 h) in Group FF10 ewes suppressed this high concentration in the other 3 groups by over $50 \%$ by the 17:00 h sample, i.e. $8 \mathrm{~h}$ after injection. In the ewes receiving bovine serum (Groups C, FF2 and FF6), plasma FSH levels were low during Days 2 and 3 and began to rise on Day 4 of the luteal phase, reaching a plateau during Day 6 in Group C and Group FF2 only. This rise was abolished by the start of follicular fluid administration in Group FF6. A significant depression in plasma concentrations of FSH occurred after the first follicular fluid injection on Days 5 and 9 in Groups FF6 and FF2 respectively. In all ewes in Groups FF2, FF6 and FF10, irrespective of stage of cycle, plasma FSH levels were lower at the 17:00 $\mathrm{h}$ sample ( $8 \mathrm{~h}$ from injection) than at the $09: 00 \mathrm{~h}$ sample $(16 \mathrm{~h}$ from last injection), reflecting the start of the early morning (06:00 h onward) rebound in FSH levels reported by Wallace \& McNeilly (1985).

After cloprostenol-induced luteolysis on Day 11 of the cycle, plasma levels of FSH did not alter significantly in Group C ewes. In contrast, mean FSH levels in all ewes in Groups FF2, FF6 and FF10 increased after luteolysis, reaching a peak about $24 \mathrm{~h}$ after cloprostenol injection, $41 \mathrm{~h}$ after the final follicular fluid injection. The magnitude of this increase in plasma concentrations of FSH was correlated with the length of luteal-phase treatment in a dose-response manner.

Basal concentrations of $\mathrm{LH}$ in twice daily samples were significantly higher $(P<0.001)$ in Group FF10 ewes than in those in Group C throughout the luteal phase of the cycle (Text-fig. 2). In contrast, levels of LH in ewes in Groups FF2 and FF6 were not significantly different from those of Group $\mathrm{C}$ ewes irrespective of stage of cycle or treatment (data not shown). In addition, there were no significant differences in the plasma level of $\mathrm{LH}$ measured at 09:00 $\mathrm{h}$ compared with 17:00 $\mathrm{h}$ in any of the control or treated ewes.

There was no significant effect of treatment on plasma concentrations of FSH or LH during the subsequent oestrous cycle or early pregnancy.

Plasma concentrations of progesterone. There were no significant differences in plasma progesterone concentrations between groups during the treatment cycle. Initially, on Days 1 and 2 , plasma progesterone levels were $<0.1 \mathrm{ng} / \mathrm{ml}$, characteristic of oestrus. Levels began to rise on Days 3-4 of the cycle, reaching a plateau by Day 7 . Thereafter, the mean progesterone concentration in ewes in Group FF2 was slightly lower than that of controls, although this difference was not significant.

The 2 ewes that returned to oestrus 18 days after mating had progesterone concentrations typical of those measured during a normal oestrous cycle. Similarly, the progesterone levels of 2 ewes 


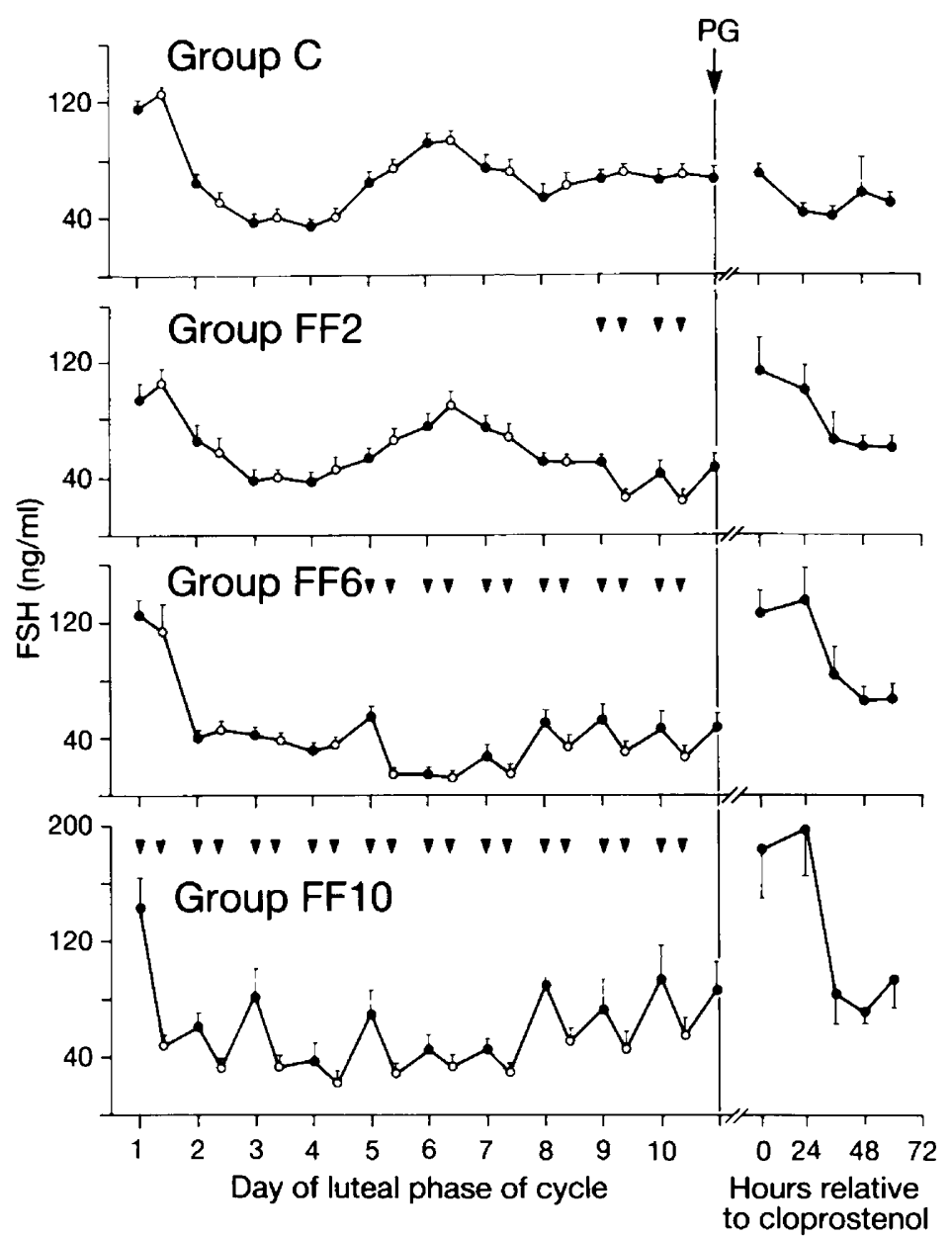

Text-fig. 1. Changes in the plasma concentrations of FSH in blood samples withdrawn before injection of bovine follicular fluid $(\nabla)$ at $09: 00 \mathrm{~h}(\Theta)$ and 17:00 h (O) for (a) 0 (Group C), (b) 2 (Group FF2), (c) 6 (Group FF6), or (d) 10 (Group FF10) days during the luteal phase of the cycle. After cloprostenol-induced luteolysis samples were withdrawn at $24,36,48$ and $60 \mathrm{~h}$. Values are mean \pm s.e.m.

found not to be pregnant at slaughter returned to basal levels $(<0 \cdot 1 \mathrm{ng} / \mathrm{ml})$, characteristic of oestrus, between Days 17 and 19, although they did not show behavioural oestrus as detected by a vasectomized ram.

As samples were withdrawn every 2 nd or 3 rd day during the first 20 days of gestation, the data were analysed as the mean progesterone concentration per 3-day block, behavioural oestrus representing Day 0 . Analysis of the progesterone concentrations of the 34 pregnant ewes showed that there were no significant differences between treatment groups during the first 20 days of gestation. Plasma progesterone levels began to rise on Days 3-5 of pregnancy, reaching a plateau by Days $9-11$. When the individual progesterone profiles were grouped and analysed according to ovulation rate (irrespective of previous treatment), the mean ( \pm s.e.m.) progesterone concentration was higher in ewes with 4 or more corpora lutea $(4.9 \pm 0.2 \mathrm{ng} / \mathrm{ml} ; \mathrm{N}=18)$ compared with those having 2 or 3 corpora lutea $(4 \cdot 1 \pm 0 \cdot 2 \mathrm{ng} / \mathrm{ml} ; \mathrm{N}=16)$ between Days 9 and 20 of gestation. However, this difference failed to reach significance. Similarly, there were no significant differences in the mean progesterone concentrations when analysed according to the number of embryos surviving at slaughter. 


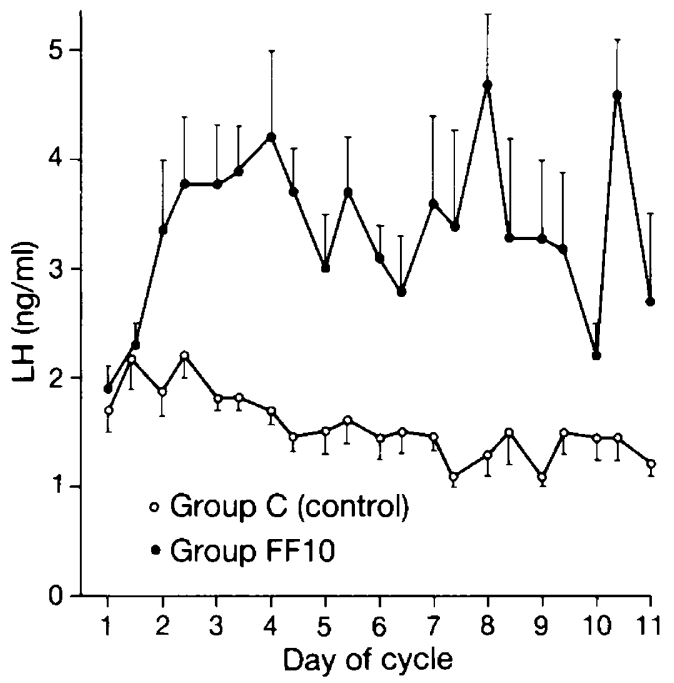

Text-fig. 2. Changes in plasma concentrations of LH on Days 1-11 of the cycle before injection of bovine serum $(O)$ or bovine follicular fluid $(O)$ at 09:00 and 17:00 h. The profiles of ewes in Groups FF2 and FF6 were not significantly different from those of Group C ewes and are excluded for clarity.

\section{Discussion}

The results of the present study show that administration of bovine follicular fluid during the luteal phase of the cycle for various lengths of time (2, 6 or 10 days), before the induction of luteolysis with cloprostenol, increased ovulation rate. This confirms and extends our previous observations using an 11-day treatment regimen (Wallace \& McNeilly, 1985). However, contrary to previous observations following administration of bovine follicular fluid in both the luteal (Wallace \& McNeilly, 1985) and follicular phase (Miller, Critser, Rowe \& Ginther, 1979; McNeilly, 1984) of the cycle, the onset of behavioural oestrus was not significantly delayed in the present study. The interval between cloprostenol-induced luteal regression and the onset of oestrus in the control group was 18-24 h later than that previously observed for Damline ewes (Wallace \& McNeilly, 1985). It seems likely that other environmental factors may have masked any differences between groups in that ewes were studied early in the breeding season in the continued presence of rams. Since the potency of the bovine follicular fluid used in this study was similar $(11976 \mathrm{U} / \mathrm{ml}$ compared with $13110 \mathrm{U} / \mathrm{ml}$ ) to that used in our earlier study (Wallace \& McNeilly, 1985) in which significant delays in onset of oestrus relative to controls were recorded, differences in follicular fluid potency do not appear to be the cause.

The conception rate in the present study was high and was not affected by follicular fluid treatment or ovulation rate. This confirms our previous work which showed that, although the onset of oestrus and the preovulatory LH surge had been delayed after treatment with follicular fluid in the previous luteal phase, the interval from oestrus to the preovulatory LH surge was not altered (Wallace \& McNeilly, 1985). As fertilization is normally an 'all or nothing' event in the sheep (Restall, Brown, Blockey, Cahill \& Kearins, 1976) and conception rate was high, it seems unlikely that partial failure of fertilization was responsible for any of the embryo loss observed in the study.

The majority of embryo loss occurs during the first month of pregnancy in the ewe (Robinson, 1951; Quinlivan, Martin, Taylor \& Cairney, 1966); therefore, by slaughtering ewes at Day 30-34 of gestation, a true projection of litter size at term is assumed. Estimates of normal embryo loss during this early stage of pregnancy range from 20 to $30 \%$ (Edey, 1976). Thus, the overall embryo loss, irrespective of treatment, in the present study $(37 \%)$ was higher than expected. However, the study 
was completed early in the breeding season using $1 \frac{1}{2}-2 \frac{1}{2}$-year-old ewes and both factors are known to contribute substantially to embryonic loss (Hulet, Voigtlander, Pope \& Casida, 1956; Cumming, Blockey, Winfield, Parr \& Williams, 1975; Blockey, Parr \& Restall, 1975; Restall et al., 1976). Nevertheless, it is believed that in the present study the higher ovulation rate per se was the major cause of the embryo loss observed, particularly in the ewes treated with bovine follicular fluid. Previous studies using the prolific Finnish Landrace $\times$ Dorset Horn sheep treated with PMSG (Rhind, Robinson, Fraser \& McHattie, 1980) have shown that with each increase in ovulation rate above 5, there was a reduction in the percentage of ova represented by viable fetuses at the time of slaughter. Similarly, data from embryo transfer studies (Land \& Wilmut, 1977) have shown that doubling the number of embryos transferred resulted in a decrease in the number of lambs born. As the optimum ovulation rate for maximum survival was found to be 3 ova in the present study it is perhaps not surprising that in the ewes treated with follicular fluid for 10 days (and to a lesser extent in those treated for 2 and 6 days) mean embryonic survival decreased. Consequently, the higher ovulation rate was not proportionally reflected by an increase in viable embryos, although the mean number of embryos in the 10- and 6-day treatment groups was higher. Furthermore, the small incidence of detectable embryonic death was not attributed to follicular fluid treatment as it occurred in only 3 ewes, of which 1 was a control.

The results of this study give further support to the suggestion made previously (Wallace $\&$ McNeilly, 1985) that the hypersecretion or rebound of FSH during the follicular phase after termination of follicular fluid treatment at luteolysis allows more follicles to mature and ovulate. As the magnitude, and possibly the duration, of this rebound was positively correlated with the length of follicular fluid treatment, it seems possible that ewes in the 10-day treatment group had more FSH accumulated in their pituitary stores due to the longer period of low FSH release produced by the follicular fluid injections. The early morning elevation in FSH levels as detected by the 09:00 h sample (Day 2 onwards) is thought to reflect the start of release from the pituitary stores which is always terminated by the subsequent injection. It is only at luteolysis and the cessation of follicular fluid treatment that the full rebound and release of FSH from the pituitary gonadotrophs proceeds. Active immunization of sheep with inhibin partly purified from bovine follicular fluid (Henderson, Franchimont, Lecomte-Yerna, Hudson \& Ball, 1984) also resulted in an increase in ovulation rate. However, immunization had no significant effect on plasma FSH or LH concentrations as assayed in thrice weekly samples. The authors acknowledged, however, that in view of the rapidity of response and the initial lack of detectable antibodies after immunization, the inhibin preparation itself may have had a direct action on the pituitary.

The possible contribution of higher LH levels to the additional increase in ovulation rate observed in the 10-day treatment group is uncertain (see 'Discussion' by Wallace \& McNeilly, 1985). However, as LH concentrations in the 2- and 6-day treatment groups were not different during treatment relative to those in controls, the higher $\mathrm{LH}$ values in the ewes treated for 10 days may simply be a reflection of prolonged FSH suppression resulting in low oestradiol production by the follicles, and consequently a lack of negative feedback from the ovary on pulstile LH release as suggested previously (Wallace \& McNeilly, 1985).

In conclusion, the present study has shown that the increase in ovulation rate observed after treatment of Damline ewes with follicular fluid during the luteal phase of the cycle can be expected to yield increased lambing percentages. The use of follicular fluid treatments in less prolific breeds, however, may potentially be more commercially important and warrants further investigation.

We thank Miss N. Anderson and Mr R. Aitken for skilled practical assistance; Miss M. Fordyce and the staff at ABRO Dryden Field Station for performing the laparoscopies; Dr C. G. Tsonis for determining the inhibin potency; Mr T. McFetters and Mr E. Pinner for preparation of the figures and Mrs A. Shaw for typing. J.M.W. is in receipt of a postgraduate studentship from the Department of Agriculture and Fisheries of Scotland. 


\section{References}

Blockey, M.A. de B., Parr, R.A. \& Restall, B. J. (1975) Wastage of ova in young Merino ewes. Aust. vet. $J$. 51, 298-302.

Cumming, I.A., Blockey, M.A. de B., Winfield, C.G., Parr, R.A. \& Williams, A.H. (1975) A study of relationships of breed, time of mating, level of nutrition, live weight, body condition and face cover to embryo survival in ewes. J. agric. Sci., Camb. 84, 559-565.

Davis, I.F., Brien, F.B., Findlay, J.K. \& Cumming, I.A. (1981) Interactions between dietary protein, ovulation rate and follicle stimulating hormone levels in the ewe. Anim. Reprod. Sci. 4, 19-28.

de Jong, F.H., van Dijk, S. \& van der Molen, H.J. (1984) Purification of inhibin from bovine follicular fluid (BFF). J. Steroid Biochem. 20, Abstr. I 17.

Djahanbahkch, O., Swanston, I.A., Corrie, J.E.T. \& MeNeilly, A.S. (1981) Prediction of ovulation by progesterone. Lancet 8256, 1164-1165.

Edey, T.N. (1976) Nutrition and embryo survival in the ewe. Proc. N.Z. Soc. Anim. Prod. 36, 231-239.

Gherardi, P.B. \& Lindsay, D.R. (1980) The effect of season on the ovulatory response of Merino ewes to serum from pregnant mares. J. Reprod. Fert. 60, $425-429$.

Gunn, R.G., Doney, J.M. \& Russel, A.J.F. (1969) Fertility in Scottish Blackface ewes as influenced by nutrition and body condition at mating. J. agric. Sci., Camb. 73, 289-294.

Henderson, K.M., Franchimont, P., Lecomte-Yerna, M.J., Hudson, N. \& Ball, K. (1984) Increase in ovulation rate after active immunization of sheep with inhibin partially purified from bovine follicular fluid. J. Endocr. 102, 305-309.

Hulet, C.V., Voigtlander, H.P., Pope, A.L. \& Casida, L.E. (1956) The nature of early season infertility in sheep. J. Anim. Sci. 15, 607-616.

Land, R.B. \& Wilmut, I. (1977) The survival of embryos transferred in large groups to sheep of breeds with different ovulation rates. Anim. Prod. 24, 183-187.

Martensz, N.D., Baird, D.T., Scaramuzzi, R.J. \& Van Look, P.F.A. (1976) Androstenedione and the control of luteinizing hormone in the ewe during anoestrus. J. Endocr. 69, 227-237.
McNeilly, A.S. (1984) Changes in FSH and the pulsatile secretion of LH during the delay in oestrus induced by treatment of ewes with bovine follicular fluid. $J$. Reprod. Fert. 72, 165-172.

MeNeilly, J.R., McNeilly, A.S., Walton, J.S. \& Cunningham, F.J. (1976) Development and application of a heterologous radioimmunoassay for ovine follicle-stimulating hormone. J. Endocr. 70, 69-79.

Miller, K.F., Critser, J.K., Rowe, R.F. \& Ginther, O.J. (1979) Ovarian effects of bovine follicular fluid treatment in sheep and cattle. Biol. Reprod. 21, 537-544.

Quinlivan, T.D., Martin, C.A., Taylor, W.B. \& Cairney, I.M. (1966) Estimates of pre- and perinatal mortality in the New Zealand Romney Marsh ewe. 1. Pre- and perinatal mortality in those ewes that conceived to one service. J. Reprod. Fert. 11, 379-390.

Restall, B.J., Brown, G.H., Blockey, M. de B., Cahill, L. \& Kearins, R. (1976) Assessment of reproductive wastage in sheep. 1. Fertilisation failure and early embryonic survival. Aust. J. exp. Agric. Anim. Husb. 16, 329-335.

Rhind, S.M., Robinson, J.J., Fraser, C. \& McHattie, I. (1980) Ovulation and embryo survival rates and plasma progesterone concentrations of prolific ewes treated with PMSG. J. Reprod. Fert. 58, 139-144.

Robinson, T.J. (1951) The control of fertility in sheep. Part II. The augmentation of fertility by gonadatrophin treatment of the ewe in the normal breeding season. J. agric. Sci., Camb. 41, 6-63.

Tsonis, C.G., Quigg, H., Lee, V.W.K., Leversha, L., Trouson, A.O. \& Findlay, J.K. (1983) Inhibin in individual ovine follicles in relation to diameter and atresia. J. Reprod. Fert. 67, 83-90.

Van Look, P.F.A., Clarke, I.J., Davidson, W.G. \& Scaramuzzi, R.J. (1978) Ovulations and lambing rates in ewes actively immunized against androstenedione. J. Reprod. Fert. 53, 129-130.

Wallace, J.M. \& McNeilly, A.S. (1985) Increase in ovulation rate after treatment of ewes with bovine follicular fluid in the luteal phase of the oestrous cycle. $J$. Reprod. Fert. 73, 505-515.

Received 21 November 1984 